International Journal of Advancement in Life Sciences Research

Online ISSN: 2581-4877

journal homepage http://ijalsr.org

Original Article

\title{
Development of Termitomyces Protoclones and Characterizations Through PCR Based ISSR And RFLP of rRNA-ITS Gene
}

\author{
Purbasa Pal ${ }^{1}$, Joyaty Sanyal ${ }^{1}$, Dipanwita Roy ${ }^{2}$, Samir Ranjan Sikdar ${ }^{2}$ and Pijush Mallick ${ }^{{ }^{1,2}}$ \\ ${ }^{1}$ Department of Biotechnology, School of Biotechnology \& Biosciences, Brainware University, \\ 398 Ramkrishnapur Road, Barasat, North 24 Parganas, Kolkata 700125, India \\ ${ }^{2}$ Division of Plant Biology, Bose Institute, P1/12, C.I.T., Scheme VII M, Kakurgachhi, Kolkata 700054, India
}

Correspondence E-mail :purbasapal3@gmail.com, joyaty.sanyal@gmail.com, dipanwitaroy987@gmail.com, samir@jcbose.ac.in, biology.pijush@gmail.com*

\begin{abstract}
A total of five protoclones were successfully cultured on PDA medium out of regenerated twenty two colonies of Termitomyces protoplast and further studied. Liquid MYG grown mycelial tissue is used for protoplast isolation by enzymatic digestion in a mixture containing Lysing enzyme $2 \%$ and Cellulase $\mathrm{R} 102 \%$ in $0.6 \mathrm{M}$ mannitol. The incubation conditions like temperature, shaking and time were standardized at $24^{\circ} \mathrm{C}$ with shaking $60 \mathrm{rpm}$ for 10 hours, respectively for healthy protoplasts liberation. The purified protoplasts showed $31.60 \pm 9.31 \%$ regeneration on specific medium and $77.12 \pm 2.72 \%$ viability by FDA test. Four ISSR primers were used in this study with a total of 27 reproducible bands with mean value 6.75 and they showed similar banding pattern in all with zero percent polymorphism ranged from $280 \mathrm{bp}-2700 \mathrm{bp}$. The amplified rRNA-ITS gene showed $\sim 600 \mathrm{bp}$ size in gel and found a single restriction site for enzyme Haelll in all the protoclones and parent with similar fragment size in all.
\end{abstract}

Keywords: DNA markers, Edible mushroom, Genome stability, Protoplast regeneration.

\section{Introduction}

Edible mushrooms are rich in protein content and thus used as food supplement worldwide. They can be commercially cultivated but still the wild collection is very popular to the poor tribal family in Asian and African countries. Termitomyces $s p$. is such popular wild edible mushroom grows in termite gut and found in Birbhum, Purulia and Midnapore districts of West Bengal, India. Apart from protein, Termitomyces is an affluent source of sugar, fibre, lipid, vitamin, mineral in addition to medicinal value which is used in lower blood pressure, rheumatism, kwashiorkor, obesity, diarrhea and purgative (Apetorgbor et al, 2005; Rajoriya et al, 2014). So, it is now an important issue to improve the Termitomyces strains in terms of substrate specificity, yield and nutritional attributes. The mushroom crop improvement includes the two major aspects i.e., genome shuffling via protoplast technology and development of transgenic via genetic engineering. Due to the lack of available genetic resources and many other disadvantages, researchers prefer the protoplast fusion technology for mushroom breeding where even mating can be possible between the sexually incompatible strains (Mallick and Sikdar 2014, 2015a). However, it has been proved that the protoplasts are good source material for mushroom crop 
improvement (Chakraborty and Sikdar, 2010; Mallick and Sikdar, 2014, 2015a) where researchers had successfully developed somatic hybrids between the different genera followed by fruit body production. Development of Termitomyces protoplast and study about their genome stability is a crucial factor for its breeding with other strains. Sometimes, the fruit body derived mushroom strains show genome instability with their parent (Mallick and Sikdar, 2015b) analyzed by molecular DNA markers.

In the past, Nazrul and Yin-Bing (2010) developed ten protoclones of Agaricus bisporus and characterized those using morphological and molecular parameters. They showed the genome instability in the protoclones analyzed by ISSR markers. ISSR is a reproducible molecular DNA marker for genetic analysis (Bornet and Branchard 2001) and hence have been used to study the genetic diversity of mushrooms (Guan et al., 2008; Nazrul and Yin-Bing, 2010; Malekzadeh et al., 2011; Mallick and Sikdar, 2014, 2015a).

However, in this study we wanted to study about the genome stability of Termitomyces heimii protoclone developed by mycelial protoplast and characterization of those by PCR based molecular DNA markers.

\section{Materials and Methods}

Protoplast isolation, purification and culture:

The Termitomyces heimii fruit body was collected from Bankura district of West Bengal, India and routinely maintained the vegetative culture on PDA medium (Potato Dextrose Agar, $\mathrm{pH} 6.2$ ) at $28^{\circ} \mathrm{C}$. The 7 days old MYG $(10 \mathrm{~g} / \mathrm{l}$ malt extract, $4 \mathrm{~g} / \mathrm{l}$ yeast extract and 10 $\mathrm{g} / \mathrm{l}$ glucose, $\mathrm{pH}$ 6.2) grown mycelial tissue was used for enzymatic digestion. Protoplast isolation and purification was done according to the protocol of Mallick \& Sikdar, 2014. Protoplast yield was measured using a hemocytometer and viability was calculated by FDA staining (Widholm, 1972). Culture media containing MYG supplemented with $0.7 \mathrm{M} \mathrm{NaCl}$ as an osmotic stabilizer and $1.5 \%$ agar with purified protoplast was kept at $28^{\circ} \mathrm{C}$ for regeneration.
Extraction of genomic DNA and ISSR:

The genomic DNA was extracted from MYG grown mycelial tissues using modified CTAB method (Dellaporta et al.. 1983). Four ISSR primers were used (Table1) in each single reaction according to the protocol of Bornet and Branchard (2001) with slight modifications. The PCR was performed in 25 $\mu \mathrm{l}$ of reaction volume in a DNA thermal cycler (Applied Bio-systems 2027) containing 25ng template DNA, 10X Taq buffer $(+\mathrm{KCl}), 25 \mathrm{mM}$ $\mathrm{MgCl}_{2}, 2 \mathrm{mM}$ dNTPs mix, primer and Taq DNA polymerase $(5 \mathrm{U} / \mu \mathrm{l})$. The initial denaturation at $94^{\circ} \mathrm{C}$ for $5 \mathrm{~min}$, followed by 40 cycles consisting of denaturation at $94^{\circ} \mathrm{C}$ for $1 \mathrm{~min}$, primer annealing $\left(37-61^{\circ} \mathrm{C}\right)$ for $1 \mathrm{~min}$ and extension at $72^{\circ} \mathrm{C}$ for $3 \mathrm{~min}$ and a final extension for $10 \mathrm{~min}$ at $72^{\circ} \mathrm{C}$.

Amplification of rRNA-ITS gene and RFLP:

According to the protocol of White et al. (1990), the rRNA-ITS gene was amplified by $\mathrm{PCR}$ in a $25 \mu \mathrm{l}$ of reaction volume containing 15ng template DNA, 10X Taq buffer $(+\mathrm{KCl})$, $25 \mathrm{mM} \mathrm{MgCl} 2,2 \mathrm{mM}$ dNTPs, primer ITS1-F(5' TCCGTAGGTGAACCTGCGG $3^{\prime}$ ) and ITS4$\mathrm{R}\left(5^{\prime} \quad\right.$ TCCTCCGCTTATTGATATGC 3') (Table1), Taq DNA polymerase $(5 \mathrm{U} / \mu \mathrm{l})$. The amplification was conducted in a DNA thermal cycler (Applied Bio-systems 2027) by preliminary denaturation at $95^{\circ} \mathrm{C}$ for $4 \mathrm{~min}$ followed by 40 cycles; denaturation at $94^{\circ} \mathrm{C}$ for $1 \mathrm{~min}$, primer annealing at $55^{\circ} \mathrm{C}$ for $1 \mathrm{~min}$, initial extension at $72^{\circ} \mathrm{C}$ for $1 \mathrm{~min} 30 \mathrm{sec}$, followed by a final extension at $72^{\circ} \mathrm{C}$ for $8 \mathrm{~min}$.

For restriction analysis, PCR products were purified by sodium acetate precipitation. $10 \mu \mathrm{l}$ of purified PCR product was used for restriction digestion according to the supplier's specification with enzyme Haelll (Fermentas).

Gel run:

ISSR fragments, rRNA-ITS products and restriction digested products were separated on $1.8 \%, 1.5 \%$ and also $1.5 \%$ agarose gel with pre-stained ethidium bromide solution using 1X TAE buffer, respectively. The gels were run at 80 volts for $3 \mathrm{hrs}$ (ISSR), 2 hrs (rRNA-ITS) and 3 hrs (RFLP) and banding profiles were visualized under UV light using a transilluinator system. Data were recorded in a Molecular Analyst Gel Documentation System. Gene 
Ruler 100 bp plus DNA ladder, (MBI, Fermentas) is used as a standard molecular weight marker in each case.

\section{Results}

Protoplast culture and regeneration:

The enzyme mixture containing lysing enzyme $2 \%$ and cellulase R10 2\% in $0.6 \mathrm{M}$ mannitol as osmoticum showed the best result with gentle shaking at $60 \mathrm{rpm}$ for $10 \mathrm{hrs}$ at $24^{\circ} \mathrm{C}$. The average yield of purified protoplast was $1.2 \times 10^{7} \mathrm{cells} / \mathrm{gm}$ of 7 days old tissues (Fig.1a) as optimum. They showed the maximum $31.60 \pm 9.31 \%$ regeneration and $77.12 \pm 2.72 \%$ viability (Fig.1C). The purified protoplasts (Fig.1b) were cultured on MYG medium supplemented with $0.7 \mathrm{M} \mathrm{NaCl}$ and $1.5 \%$ agar, $\mathrm{pH} 6.2$ and kept at $28^{\circ} \mathrm{C}$ for regeneration.

Table1: Details of primers used in this study.

\begin{tabular}{|c|c|c|c|c|}
\hline SI No. & Primer Name & $\begin{array}{c}\text { Sequence }\left(5^{\prime}-3^{\prime}\right) \\
\text { with repeat motif }\end{array}$ & $\begin{array}{c}\text { No. of amplified } \\
\text { bands }\end{array}$ & $\begin{array}{c}\text { Size range in } \\
\text { bp }\end{array}$ \\
\hline 1. & ISSR-01 & $\begin{array}{c}\text { GACAGACAGACAGACA } \\
{[(\text { GACA } 4]}\end{array}$ & 5 & $520-1850$ \\
\hline 2. & ISSR-02 & $\begin{array}{c}\text { CAGCAGCAGCAGCAG } \\
{[(\text { CAG)5] }}\end{array}$ & 7 & $350-2200$ \\
\hline 3. & ISSR-11 & $\begin{array}{c}\text { CACCACCACGC } \\
{[(\text { CAC)3GC] }}\end{array}$ & 6 & $280-2700$ \\
\hline 4. & ISSR-12 & $\begin{array}{c}\text { GAGGAGGAGGC } \\
{[(\text { GAG)3GC] }}\end{array}$ & 9 & 600 \\
\hline 5. & $\begin{array}{l}\text { ITS1-F } \\
\text { ITS4-R }\end{array}$ & $\begin{array}{c}\text { TCCGTAGGTGACCTGCGG } \\
\text { TCCTCCGCTTATTGATATGC }\end{array}$ & 1 & \\
\hline
\end{tabular}
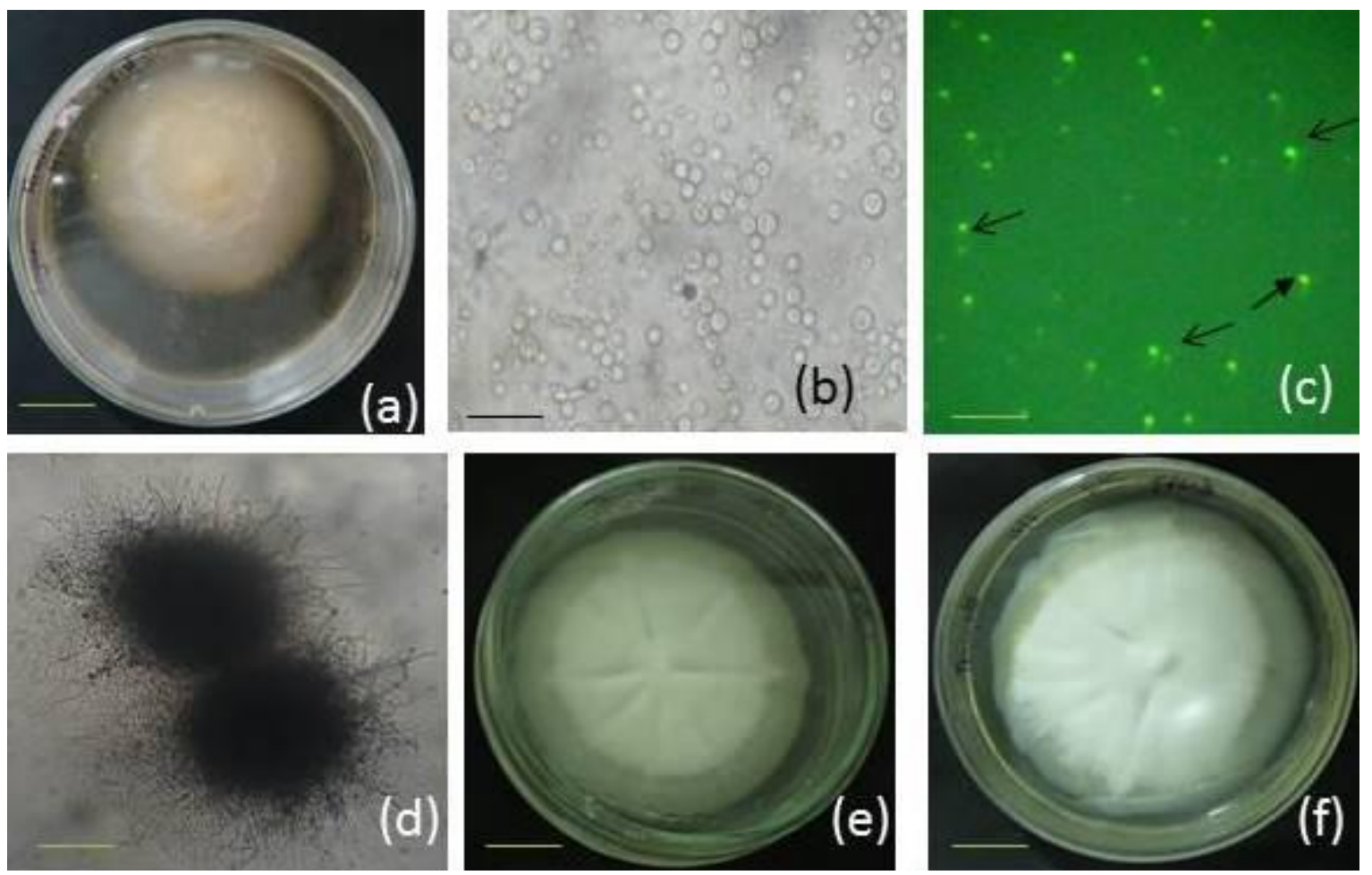

Fig.1: (a) 7days old liquid culture of Termitomyces, (b) Purified protoplasts in $0.6 \mathrm{M}$ mannitol isolated from liquid-grown tissue, (c) FDA stained viable protoplasts, (d) Developed 3 days old micro-colonies on regeneration medium, (e) 7days old PDA culture of TPC1, (f) 7days old PDA culture of TPC5. Bar size: $20 \mathrm{~mm}$ in (a), (e) \& (f). $60 \mu \mathrm{m}$ in (b), $100 \mu \mathrm{m}$ in (c) and (d) 
Protoplast started germ tube formation in 24 hrs followed by micro-colonies (Fig.1d) formation in 72 hrs onwards. A total of twenty two macro-colonies were observed in four replicate regeneration plates after 5, 7 (from two replicate) and 8 days, respectively. Immediately, the colonies were transferred in PDA medium for further growth and kept at $28^{\circ} \mathrm{C}$. Among them only five putative protoclones were selected based on their growth performance and named as TPC1, TPC2, TPC3, TPC4 and TPC5 (Fig.1e\&f).

\section{ISSR profile:}

Four reproducible ISSR primers amplified a total of 27 bands in all the TPC lines including parent with mean value of 6.75 . ISSR-01 produced the lowest number of band i.e., 5 and ranged from 520 bp -1850 bp where ISSR-12 produced the highest number of band i.e., 9 and ranged from $280 \mathrm{bp}-2700 \mathrm{bp}$ (Table1). All the TPC lines showed similar banding patterns in size and number with the parent using ISSR primers (Fig.2). However, the ISSR profiles resulted that there is no dissimilarities or polymorphism in all the protoclones with respect to the parent.

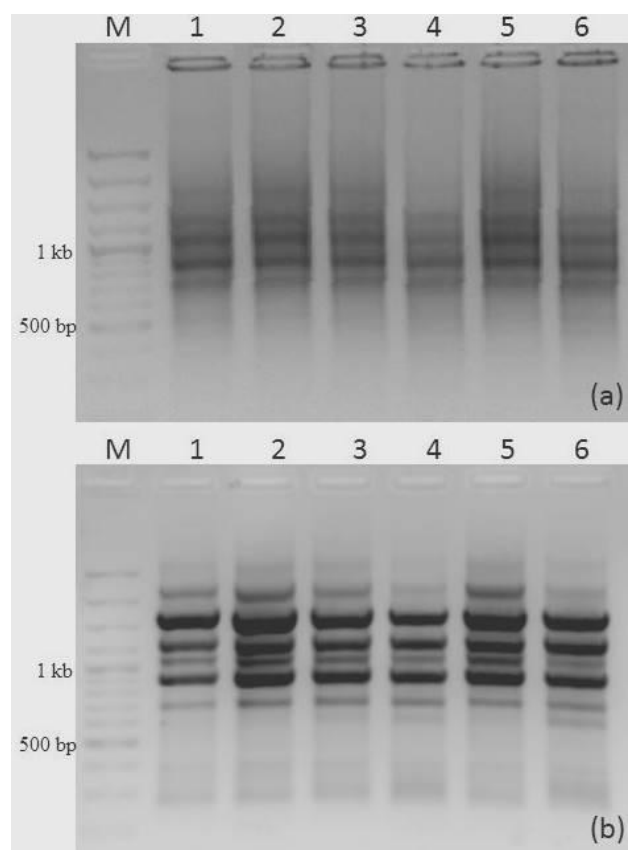

Fig. 2: ISSR profiles of TPC cultures and parent Termitomyces generated by (a) ISSR11 and (b) ISSR-12. Lanes: M - molecular weight markers, $100 \mathrm{bp}$ DNA ruler plus, lane1 - parent Termitomyces and lane $2-6$ is TPC $1-5$, respectively
Amplification of rRNA-ITS region and RFLP analysis:

The primer set ITS1(F) and ITS4(R) amplified the rRNA-ITS gene in all the TPC lines and parent and the size was analyzed in agarose gel. The PCR product showed a single band in all the lines with approx. $600 \mathrm{bp}$ in size (Fig.3a). The primer set ITS1(F) and ITS4(R) can amplify only the ITS1-5.8S-ITS2 region which is basically a conserved sequence. We also found that the TPC lines are genetically similar with the parent by the restriction enzyme digestion. The restriction enzyme Haelll showed only single restriction site in the entire ITS1-5.8S-ITS2 region in all the lines including parent followed by producing two bands in the gel (Fig.3b). It was also noted that the sizes of restriction fragments were same in all.

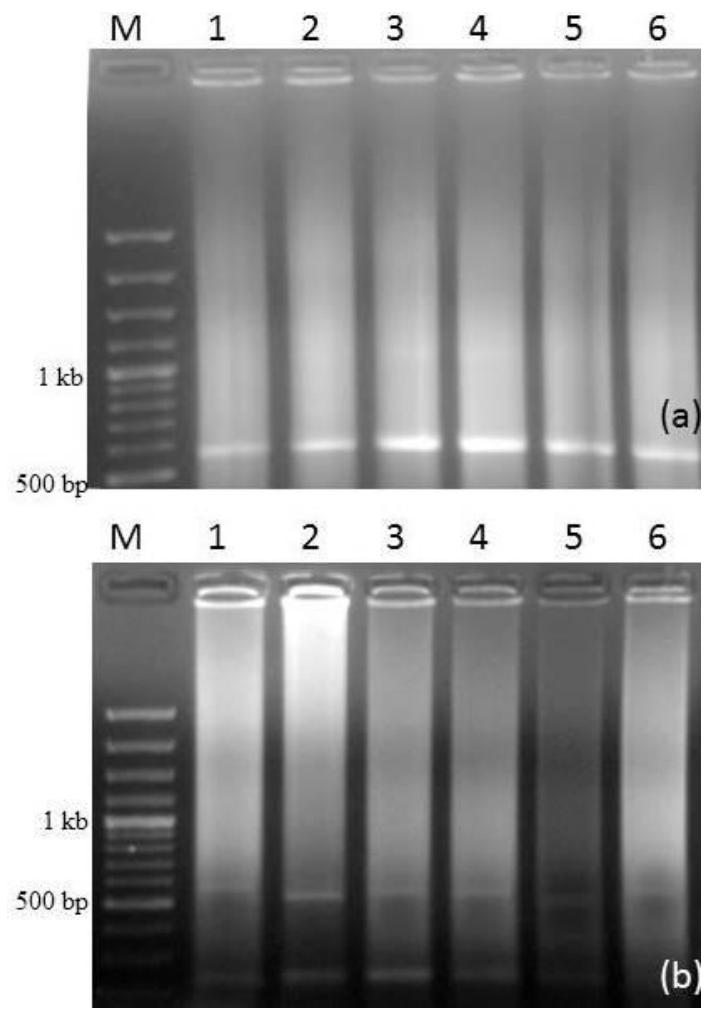

Fig.3: The rRNA-ITS gene and RFLP profile of TPC lines and parent Termitomyces. (a) Amplified rRNA-ITS gene showing approx. 600 bp size in gel, (b) RFLP profile by restriction enzyme Haelll. Lanes: M - molecular weight markers, 100 bp DNA ruler plus, lane1 parent Termitomyces and lane $2-6$ is TPC 1 -5 , respectively 


\section{Discussion}

Development of protoclone of agricultural crop usually helps in breeding for development of superior quality lines. In plant system several reports have been made where protoclone is developed from the protoplast and interestingly they showed phenotypic diversity where genotypic identity was maintained (Gill et al. 1986) and vice-versa (Kane et al. 1992). Theoretically, protoclones are identical lines of the existing parent whether it may be plant, animal, fungi or other living organisms. For rapid multiplication of crop plant and mammalian cell lines this technique is used in tissue culture industry.

Reports on characterization of mushroom protoclone are limited and it depends on the regeneration percentage of protoplast in the suitable culture medium. Isolation and purification of Termitomyces protoplast was carried out following the standardized protocol with slight modifications and the protoplasts were cultured in such suitable medium where the regeneration percentage was highly achieved. However, the resulted genetic structures were identical in all the TPC lines with parent based on ISSR profile and RFLP of rRNA-ITS gene. The ISSR, RFLP of rRNAITS gene has already been proved as reproducible and suitable genetic markers for analysis of mushroom somatic hybrids and fruit body derived lines (Mallick and Sikdar 2014, 2015a \& 2016). Even the mushroom

\section{References}

Apetorgbor MM, Apetorgbor AK and Nutakor E (2005) Utilization and cultivation of edible mushrooms for rural livelihood in Southern Ghana. $17^{\text {th }} \quad$ Commonwealth Forestry Conference, Colombo, Sri Lanka

Bornet B and Branchard M (2001) Nonanchored Inter Simple Sequence Repeat (ISSR) Markers: Reproducible and Specific Tools for Genome Fingerprinting. Plant Molecular Biology Reporter, 19: 209-215.

Chakraborty U and Sikdar SR (2010) Intergeneric protoplast fusion between Calocybe indica (milky mushroom) and Pleurotus florida aids in the qualitative and fruit body derived lines showed genetic diversity which might be occurred due to the gene environmental factor followed by elimination or rearrangement of genome structure during subsequent culture (Mallick and Sikdar, 2015). In this case, all the TPC lines are genetically identical with little morphological dissimilarity like heterogeneous colony nature, growth rate on PDA medium (not details in this manuscript). This might be happen due to the presence of inactive compounds in the medium or the protoplast cultures were not exposed to the environment where direct gene environmental factor works.

\section{Conclusion}

The morphological variation may be due to the effects of vegetative culture or the growth responsive gene might be in the dominant allele or induced during sub-culturing. Once the genetic makeup remains identical in this case, we could claim that these lines are clone which are derived from the protoplast. The further study regarding their yield, detail morphological attributes, nutritional profiles of the existing cloud give a good conclusion.

\section{Acknowledgement:}

Authors are thankful to the Director of Bose Institute, Head, Division of Plant Biology section, Vice Chancellor and Registrar of Brainware University, Kolkata, India for providing all the necessary facilities and support.

quantitative improvement of sporophore of the milky mushroom. World Journal of Microbiology \& Biotechnology, 26: 213-225.

Dellaporta SL, Wood J and Hicks JB (1983) A plant DNA minipreparation: version II. Plant Molecular Biology Reporter, 1: 19-21.

Gill BS, Kam-Morgan LNW and Shepard JF (1986) Origin of chromosomal and phenotypic variation in potato protoclones. Journal of Heredity, 77(1): 13-16.

Guan XJ, Xu L, Shao YC, Wang ZR, Chen FS and Luo XC (2008) Differentiation of commercial strains of Agaricus species in China with inter-simple sequence repeat 
marker. World Journal of Microbiology \& Biotechnology, 24: 1617-1622.

Kane EJ, Wilson AJ, Chourey PS (1992) Mitochondrial genome variability in Sorghum cell culture protoclones. Theoretical and Applied Genetics, 83: 799-806.

Malekzadeh K, Shahri BJM and Mohsenifard E (2011) Use of ISSR markers for strain identification in the button mushroom, Agaricus bisporus. Proceedings of the 7th International Conference on Mushroom Biology and Mushroom Products (ICMBMP7), pp.30-34.

Mallick P and Sikdar SR (2014) Production and molecular characterization of somatic hybrids between Pleurotus florida and Lentinula edodes. World Journal of Microbiology and Biotechnology, 30(8): 22832293.

Mallick P and Sikdar SR (2015a) Fruit body production and characterization of hybrid edible mushroom strains developed by protoplast fusion between Pleurotus florida and Lentinus squarrosulus. International Journal of Pharma and Bio Sciences, 6(3): 301-314.
Mallick P and Sikdar SR (2015b) Genome instability in fruit body derived lines generated from fruiting pfle somatic hybrid lines and development of hybrid strain specific SCAR marker in edible mushroom. Journal of Horticultural Research, 23(2): 111-120.

Mallick P and Sikdar SR (2016) Restriction fragment length polymorphism and sequence analysis of rRNA-ITS region of somatic hybrids produced between Pleurotus florida and Lentinula edodes. Annals of Microbiology, 66: 389-395.

Nazrul MI and Yin-Bing B (2010) ISSR as New Markers for Identification of Homokaryotic Protoclones of Agaricus bisporus. Current Microbiology, 60(2): 92-98.

Rajoriya A, Tripathy SS and Gupta N (2014) Nutritional and biochemical characterizations of different parts of Termitomyces eurrhizus from the Odisha. International Journal of Phytotherapy, 4(3): 136-138.

Widholm JM (1972) The use of fluorescein diacetate and phenosafranine for determining viability of cultured cells. Stain Technology, 47: 189-194. 